\title{
PERLINDUNGAN KEPENTINGAN NASIONAL DALAM PENANAMAN MODAL
}

\author{
Nadya Dara Prasetyo \\ Fakultas Hukum Universitas Brawijaya, Malang \\ Email: daranadya1@gmail.com \\ Istislam \\ Fakultas Hukum Universitas Brawijaya, Malang \\ Email: ist@ub.ac.id \\ Siti Hamidah \\ Fakultas Hukum Universitas Brawijaya, Malang \\ Email: hamidah@ub.ac.id
}

\begin{abstract}
Abstrak
Penelitian ini bertujuan untuk menganalisis secara holistik urgensi perlindungan hukum terhadap kepentingan nasional dalam penanaman modal di Indonesia, serta menemukan upaya yang tepat. Juga untuk mengetahui kesesuaian pelaksanaan perlindungan kepentingan nasional dalam penanaman modal di Indonesia dengan asas yang sekaligus sebagai sistem perekonomian nasional, yakni demokrasi ekonomi. Metode penelitian yang digunakan adalah pendekatan perundang-undangan (statute approach), pendekatan konseptual (conceptual approach) dan pendekatan historis (historical approach). Hasil penelitian menunjukkan bahwa Indonesia sebagai negara berkembang membutuhkan dana yang cukup besar untuk melakukan pembangunan nasional, pemenuhan kebutuhan ini salah satunya didapatkan melalui penanaman modal yang dilaksanakan berdasarkan Undang-Undang Nomor 25 Tahun 2007 tentang Penanaman Modal. Dimana dalam peraturan tersebut turut mensyaratkan perlindungan atas kepentingan nasional. Namun demikian dalam pengaturannya masih belum maksimal untuk memberikan perlindungan sebagaimana dimaksud, terutama bila ditinjau dari asas demokrasi ekonomi. Asas tersebut memang sudah disinggung dalam pembentukan Undang-Undang Penanaman Modal, tetapi dalam pasal 18 terdapat aturan yang memberi fasilitas khusus tertentu bagi penanam modal berkapasitas besar, dengan kriteria yang kurang dapat melindungi eksistensi UMKM dan koperasi sebagai wujud nyata demokrasi ekonomi dalam kehidupan rakyat. Hal ini tentu berpotensi menimbulkan persaingan yang tidak berimbang antara pemodal besar dan ekonomi rakyat. Berdasarkan kondisi tersebut perlu dilakukan penguatan sistem UMKM serta pengembangan koperasi. Hal ini sesuai dengan cita-cita tolong
\end{abstract}


menolong, sebagaimana amanat konstitusi. Dengan demikian akan terbentuk suatu perlindungan khusus, yang juga menempatkan UMKM dan koperasi pada tingkatan khusus sehingga memiliki peran yang signifikan dalam perekonomian nasional.

Kata Kunci: Kepentingan Nasional, Penanaman Modal, Demokrasi Ekonomi

\section{Abstract}

This research aims to analyze holistically the urgency of legal protection for the national interest in investment in Indonesia, and to find the right efforts. Also to find out the suitability of the implementation of protection of national interests in investment in Indonesia with the same principle as a national economic system, namely economic democracy. The research method used is the statutory approach (statute approach), conceptual approach and historical approach. The result of the research show that Indonesia as a developing country requires substantial funds to carry out national development, one of which is the fulfillment through investment which is carried out based on Law Number 25 of 2007 concerning Modification of Capital. Where the regulation also requires protection of national interests. However, the regulation is still not maximal in providing the protection as intended, especially when it viewed from the economic democracy principles. This principle has indeed been mentioned in the formation of the Investment Law, but in article 18 there are regulations that provide certain special facilities for large capacity investors, with criteria that are not sufficient to protect the existence of UKMKs and cooperatives as a real form of economic democracy in people's lives. This certainly has the potential to cause unequal competition between large investors and the people's economy. Based on these conditions, it is necessary to strengthen the UMKM system and develop cooperatives. This is accordance with the ideals of mutual help, as mandated by the constitution. Thus a special protection will be formed, which also places UMKMs and cooperatives at a special level so that they have a significant role in the national economy.

Keywords: National Interest, Investment, Economic Democracy.

\section{PENDAHULUAN}

Penanaman modal di Indonesia dilaksanakan berdasar pada ketentuan Undang-Undang Nomor 25 Tahun 2007 tentang Penanaman Modal (Selanjutnya disebut dengan Undang-Undang Penanaman Modal). Sebelum diundangkannya UU No. 25 Tahun 2007 tentang Penanaman Modal, praktek perjanjian nominee belum diatur secara tegas. Kitab 
Undanundang Hukum Perdata (KUH Per) maupun Undang-Undang Nomor 40 Tahun 2007 tentang Perseroan Terbatas, dan berbagai perundangundangan lainnya tidak jelas dan tidak tegas mengatur tentang praktik nominee atau melarang praktik tersebut. Praktik perjanjian nominee ini sering dikaitkan dengan prinsip kebebasan berkontrak (freedom of contract).

Notaris merupakan pihak yang sering terlibat dalam pembuatan perjanjian nominee dalam suatu akta notaril.Tujuannya untuk mengamankan aset-aset yang menjadi objek nominee tersebut padahal praktik ini sering dilatar belakangi oleh suatu itikad yang tidak baik, misalnya untuk menghindari peraturan perundangundangan yang membatasi kepemilikan warga negara asing atau lebih jauh lagi sebagai bentuk praktik pencucian uang. Dengan demikian, pada dasarnya dapat dikatakan bahwa perjanjian yang dibuat oleh Notaris tersebut justru telah mencederai wibawa dari profesi Notaris itu sendiri dan bertentangan dengan Pasal 16 ayat (1) huruf a Undang-Undang No. 2 Tahun 2014 tentang Perubahan atas Undang-Undang No. 30 Tahun 2004 tentang Jabatan Notaris yang menyatakan bahwa "dalam menjalankan jabatannya, Notaris wajib bertindak amanah, jujur, seksama, mandiri, tidak berpihak, dan menjaga kepentingan pihak yang terkait dalam perbuatan hukum".

Dalam Pasal 5 ayat 2 Undang-Undang No. 25 Tahun 2007 Tentang Penanaman Modal disebutkan bahwa penanaman modal asing wajib berbentuk perseroan terbatas berdasarkan hukum Indonesia dan berkedududkan di wilayah Indonesia, kecuali ditentukan lain dalam undangundang. Salah satu karakteristik perseroan terbatas adalah modal perusahaan yang terbagi atas sahamsaham.Saham perseroan terbatas yang dimiliki oleh warga negara asing menyebabkan status perusahaan tersebut dikategorikan sebagai perusahaan penanaman modal asing (PMA). Tidak semua kegiatan usaha dapat dilakukan oleh perusahaan PMA, demikian pula bahwa dalam perundang-undangan (Perpres No. 44 Tahun 2016 tentang Daftar Bidang Usaha yang Tertutup dan Bidang Usaha yang Terbuka dengan Persyaratan di Bidang Penanaman Modal) terdapat pembatasan kepemilikan saham yang oleh warga negara asing. Larangan dan pembatasan ini sesuai dengan tujuan dari UU No. 25 Tahun 2007 yaitu untuk membuka partisipasi yang lebih besar kepada modal nasional atau perusahaan dalam negeri.Praktik perjanjian nominee sering dipergunakan untuk menghindari ketentuan pembatasan tersebut.

Dalam regulasi tersebut terdapat beberapa pasal yang mengatur tidak diperkenankannya perlakuan yang berbeda terhadap investor asing maupun investor dalam negeri, namun juga mensyaratkan untuk mendahulukan kepentingan nasional di atas kepentingan investor dari negara lain atau penanam modal asing. Diantaranya adalah pada Pasal 3 
Ayat (1) huruf d yang menyebutkan perlakuan yang sama dan tidak membedakan asal negara sebagai salah satu asas dalam penyelenggaraan penanaman modal. Kemudian ketentuan pada Pasal 4 Ayat (2) huruf a, yang mengatur agar Pemerintah memberi perlakuan yang sama bagi penanam modal dalam negeri dan penanam modal asing dalam menetapkan kebijakan dasar penanaman modal. Serta Pasal 6 Ayat (1) yang menerangkan bahwa Pemerintah akan memberikan perlakuan yang sama kepada semua penanam modal yang berasal dari negara manapun yang melakukan kegiatan penanaman modal di Indonesia. Hal tersebut menunjukkan bahwa Indonesia telah menyesuaikan regulasi tentang investasinya dengan prinsip dasar TRIMs, yakni Most Favoured Nation dan National Treatment.

Bahwa yang perlu diperhatikan kembali, dalam Undang-Undang Penanaman Modal menyebutkan istilah "kepentingan nasional". Sebagaimana bunyi ketentuan Pasal 4 Ayat (2) huruf a: "memberi perlakuan yang sama bagi penanam modal dalam negeri dan penanam modal asing dengan tetap memperhatikan kepentingan nasional", serta bunyi Pasal 12 Ayat (3): "Pemerintah berdasarkan Peraturan Presiden menetapkan bidang usaha yang tertutup untuk penanaman modal, baik asing maupun dalam negeri, dengan berdasarkan kriteria kesehatan, moral, kebudayaan, lingkungan hidup, pertahanan, dan keamanan nasional, serta kepentingan nasional lainnya". Penyebutan istilah tersebut menjadi batasan bagi "perlakuan yang sama untuk penanam modal asing dan penanam modal dalam negeri" agar tidak melewati batas yang akan merugikan Indonesia.

Namun demikian, ketentuan tersebut kemudian menimbulkan ketidakpastian definisi serta batasan atau gambaran atas kepentingan nasional apa yang akan dilindungi secara nyata, khususnya dalam penanaman modal. Hal ini tentu menimbulkan kerancuan bagi banyak pihak, serta berpotensi menimbulkan tafsir yang melenceng dari hakikat kepentingan nasional yang sesungguhnya dimaksud dari ketentuan ini. Di samping itu, konsep perlindungan kepentingan nasional dalam penanaman modal, utamanya yang memperhatikan demokrasi ekonomi, secara konkrit masih kurang dapat tercermin dalam regulasi atau peraturan perundangundangan lain yang berkaitan dengan penanaman modal, diantaranya pada:

a) Peraturan Pemerintah Nomor 24 Tahun 2019 tentang Pemberian Insentif dan Kemudahan Investasi di Daerah

b) Peraturan Pemerintah Nomor 24 Tahun 2018 tentang Pelayanan Perizinan Berusaha Terintegrasi Secara Elektronik

c) Peraturan Presiden Nomor 16 Tahun 2012 tentang Rencana Umum Penanaman Modal 
d) Peraturan Presiden Nomor 44 Tahun 2016 tentang Daftar Bidang Usaha Yang Tertutup dan Bidang Usaha Yang Terbuka dengan Persyaratan di Bidang Penanaman Modal

e) Peraturan Badan Koordinasi Penanaman Modal Nomor 6 Tahun 2018 tentang Pedoman dan Tata Cara Perizinan dan Fasilitas Penanaman Modal

Hal tersebut di atas menunjukkan bahwa hingga saat ini kepentingan nasional kurang mendapatkan perlindungan hukum, khususnya dalam pelaksanaan penanaman modal. Sejatinya bangsa Indonesia tidak menentang asing. Tetapi tetap memberi ruang bagi modal asing, tenaga asing dan produk asing. Namun salah satu poin yang perlu diingat adalah Indonesia saat ini berada dalam tahap negara berkembang yang berupaya meningkatkan kemampuan dalam negeri. Sehingga dengan adanya aturan terkait dengan penanaman modal tersebut, tentu dapat mereduksi kepentingan nasional. Kemudian yang juga perlu diberi atensi lebih adalah semangat kepemilikan negara yang termaktub dalam Pasal 33 Ayat (2) UUD NRI 1945 yang mengamanatkan "cabang-cabang produksi yang penting bagi negara dan menguasai hajat hidup orang banyak dikuasai oleh negara". Kemudian, pada Pasal 33 Ayat (3) mengatakan bahwa "bumi, air, dan kekayaan alam yang terkandung di dalamnya dikuasai oleh negara dan dipergunakan secara maksimal untuk kepentingan rakyat".

Kepentingan nasional merupakan hal mendasar yang kerap kali dikaji, namun belum memiliki konsep dan parameter secara pasti. Khususnya dalam hal penanaman modal, kepentingan nasional semakin tergerus dengan munculnya beberapa permasalahan dalam bidang penanaman modal, khususnya pada penanaman modal asing (PMA). Yang mana sebagai akibat dari konflik tersebut, tentu entitas yang paling dirugikan adalah Negara. Berdampak setiap negara anggota WTO wajib saling mendorong promosi investasi dan melindungi setiap bentuk kegiatan penanaman modal yang dilakukan oleh investor antar negara-negara tersebut.

\section{METODE PENELITIAN}

Tulisan ini menggunakan metode penelitian hukum normatif karena fokus kajian berangkat dari kekaburan norma ${ }^{1}$, menggunakan pendekatan: statute approach, conceptual approach, serta historical approach. Tehnik penelusuran bahan hukum menggunakan tehnik studi kepustakaan (library

${ }^{1}$ Metode penelitian hukum normatif relevan diterapkan pada pengkajian hukum yang mengandung problematika norma kabur, norma kosong maupun norma konflik. Lihat Diantha, I. M. P. (2016). Metodologi Penelitian Hukum Normatif dalam Justifikasi Teori Hukum. Prenada Media. h. 12. 
research), serta teknik analisis bahan hukum menggunakan analisis historis dan analisis preskriptif.

\section{PEMBAHASAN}

\section{Urgensi Perlindungan Hukum Kepentingan Nasional}

Menurut Pasal 1 angka 3 Undang-Undang Nomor 25 Tahun 2007 tentang Penanaman Modal, Penanaman modal asing adalah kegiatan menanam modal untuk melakukan usaha di wilayah negara Republik Indonesia yang dilakukan oleh penanam modal asing, baik yang menggunakan modal asing sepenuhnya maupun yang berpatungan dengan penanam modal dalam negeri. Hal ini berarti pemilik modal secara langsung, menanggung resiko dari penanaman modal tersebut. Oleh karena itu, tidak hanya terjadi pemindahan sumber daya, tetapi juga terjadi pemberlakuan kontrol terhadap perusahaan di luar negeri Investasi merupakan salah satu faktor yang krusial bagi kelangsungan proses pembangunan atau pertumbuhan ekonomi jangka panjang.

Aliran modal dari suatu negara ke negara lainnya bertujuan untuk memperoleh pendapatan yang lebih tinggi, yang lebih produktif dan juga sebagai diversifikasi usaha. Hasil yang diharapkan dari aliran modal internasional adalah meningkatnya output dan kesejahteraan dunia. Disamping peningkatan income dan output, keuntungan bagi negara tujuan dari aliran modal asing adalah: ${ }^{2}$

1. Investasi asing membawa teknologi yang lebih mutakhir.

Besar kecilnya keuntungan bagi negara tujuan tergantung pada kemungkinan penyebaran teknologi yang bebas bagi perusahaan.

2. Investasi asing meningkatkan kompetisi di negara tujuan.

Masuknya perusahaan baru dalam sektor yang tidak diperdagangkan (nontradable sector) meningkatkan output industri dan menurunkan harga domestik, sehingga pada akhirnya akan meningkatkan kesejahteraan.

3. Investasi asing menghasilkan investasi domestik.

Dalam analisis terhadap 58 negara berkembang, Bosworth dan Collin menemukan sekitar setengah dari setiap dollar aliran modal menyebabkan meningkatnya investasi domestik.

4. Investasi asing memberikan keuntungan dalam hal meningkatkan akses pasar karena skala ekonomis

5. Investasi asing dapat berperan dalam mengatasi kesenjangan nilai tukar dengan negara tujuan (investment gap). Masuknya investasi

2 Brooks, Dalam Prabowo Siswanto, Analisis Dampak Perdagangan Bebas Terhadap Ketimpangan Pembangunan Wilayah, Artikel Ilmiah, Universitas Dipenegoro, 2011, hlm.45 
asing dapat mengatasi masalah tidak tercukupinya valuta asing yang digunakan untuk membiayai impor faktor produksi dari luar negeri.

Hal yang terlihat signifikan lainnya adalah dampak yang amat besar diterima dari PMA terhadap buruh. Sebagai salah satu contoh adalah terlihat dari pada saat Indonesia memutuskan mengikatkan diri dan bergabung lewat apa yang disebut dengan Asean Cina Free Trade Agreement (ACFTA) dengan meratifikasi Framework Agreement on Comprehensive Economic Co-opratian Between The Association of South East Asian and The People's Republic of Cina (Asean-Cina) pada tahun 2004 dan dituangkan dalam Keputusan Presiden Nomor 48 Tahun 2004. Dimana pada saat itu Indonesia sudah harus membuka pasar dalam negeri secara luas kepada Negara-negara anggota ASEAN dan Cina. ACFTA merupakan bentuk penanaman modal atau investasi berupa produk-produk yang dijajankan di pasar Indonesia dan negara anggota ASEAN lainnya. ${ }^{3}$

Adapun hal tersebut merupakan bentuk penegakan kedaulatan yang tetap pada ketentuan peraturan perundangan-undangan. Oleh karena itu, maka merupakan suatu keharusan bagi suatu negara tatkala merumuskan suatu peraturan perundang-undangan, selalu memperhatikan pada aspek kepetingan nasional. Dalam rangka mencapai hal tersebut, diperlukan politik hukum dari para pembuat peraturan perundang-undangan, agar keberadaan peraturan perundang-undangan tidak hanya sebatas aturan normatif yang kering akan semangat perlindungan terhadap kepentingan nasional. Oleh karena itu, maka peran dari politik hukum dalam konteks hukum sangat memegang peranan penting dan strategis, yang akan lebih memperhatikan kepada kepentingan nasional, khususnya di bidang penanaman modal.

\section{Perlindungan Hukum terhadap Kepentingan Nasional dalam Penanaman Modal}

Donald E. Nuechterlein mendefinisikan kepentingan nasional sebagai kebutuhan dan keinginan suatu negara berdaulat untuk berhubungan dengan negara berdaulat lainya yang berdasarkan pertimbangan lingkungan eksternal. Definisi ini memberikan gambaran perbedaan antara lingkungan eksternal dan internal suatu negara, lingkungan internal dimaknai sebagai kepentingan umum masyarakat suatu negara sedangkan lingkungan eksternal adalah pengaruh dari sistem internasional. Donald juga mengungkapkan bahwa kepentingan suatu negara-bangsa berarti

${ }^{3}$ Dwitari, Erika, Andriyanto, "Asean-Cina Free Trade Area Agreement as an International Regime: The Impact Anlysis on Asean”, Artikel Ilmiah, Jurusan Hubungan Internasional, Fakultas Sosial Politik, Universitas Indonesia, 2013, hlm.3 
kepentingan kesuluruhan masyarakat dan bukan hanya kepentingan kelompok dan para elite politik. ${ }^{4}$

Menurut Nuechterlein terdapat 4 dasar kepentingan nasional dibagi sebagai berikut: ${ }^{5}$

i) Defence Interest (Kepentingan Pertahanan): kepentingan untuk memberikan perlindungan kepada warga negara, wilayah serta ancaman kekerasan fisik yang berasal dari negara lain dan ancaman eksternal terhadap sistem pemerintahan.

ii) Economic Interest (Kepentingan Ekonomi): kepentingan negara dalam menjalin hubungan ekonomi yang baik dengan negara lain demi peningkatan kesejahteraan

iii) World Order Interest (kepentingan Tatanan Dunia): kepentingan mempertahankan kestabilan sistem politik internasional dan sistem ekonomi internasional yang memberikan keuntungan bagi negara.

iv) Ideological Interests (Kepentingan Ideologi): kepentingan ideologi adalah kepentingan untuk mempertahankan atau melindungi seperangkat nilai-nilai yang dipercayai oleh suatu bangsa dan dipahami sebagai nilai-nilai universal

Kemudian masing-masing dasar kepentingan nasional diatas akan dianalisis intensitas kepentingannya. Penting untuk menentukan seakurat mungkin intensitas kepentingan suatu negara terhadap suatu isu internasional, karena pemerintah suatu negara mungkin khawatir tentang suatu peristiwa di negara lain. Intensitas dimaknai sebagai kualitas hubungan antarnegara yang dipengaruhi oleh beberapa faktor, di antaranya: jarak dari perbatasan, komposisi pemerintah yang bersangkutan, jumlah perdagangan yang dilakukan, hubungan historis antar negara, dan lainya. ${ }^{6}$ Dengan menganalisis intensitas kepentingan suatu negara maka suatu negara akan mampu merespon isu internasional tersebut dengan sebaik mungkin sehingga tidak merugikan negara. Proses ini memengaruhi hitung-rugi pada empat kepentingan dasar yang diuraikan di atas. Untuk menganalisis proses penentuan intensitas maka digunakan 4 indikator dibawah ini: ${ }^{7}$

${ }^{4}$ Donald E Nuechterlein. National Interests and Foreign Policy: A Conceptual Framework for Analysis and Decision-Making. British Journal of International Studies. Vol. 2, 1976, Dalam Chaindra Adityas Ramadhan, Kepentingan Nasional Indonesia Terhadap Jepang dalam Japan-Indonesia Maritime Forum periode 2017-2018, Skripsi, Fakultas Ilmu Sosial dan Ilmu Politik, Universitas Lampung, 2019, hlm.20-21

${ }^{5}$ Ibid, hlm. 21

${ }^{6}$ Ibid, hlm.22

${ }^{7}$ Ibid 
i) Survival Issues: ketika kelangsungan hidup suatu negara dalam bahaya, akibat dari serangan militer ke wilayahnya atau terdapat ancaman penyerangan dari musuh. Dalam mengidentifikasi intensitas suatu kepentingan termasuk dalam survival issues harus memenuhi beberapa indikator yaitu.: ancamannya bersifat langsung dan nyata dan diperkirakan mampu menghancurkan negara lain. Berdasarkan definisi di atas maka, intentitas survival issues hanya berlaku pada kepentingan pertahanan dan tidak berlaku pada kepentingan ekonomi, tatanan dunia dan ideologi.

ii) Vital Issue: Ditandai dengan penggunaan kekuatan milter konvensional untuk mencegah serangan negara lain atau digunakan sebagai gertakan untuk mencegah konflik. Dalam jangka yang panjang vital issues dapat mengancam, politik dan ekonomi suatu negara. Hal ini sama seperti survival issues, namun pada vital issues negara masih memiliki waktu untuk mencari bantuan kepada negara lain dan bernegosiasi untuk menyelesaikan masalah atau bahkan mengancam akan menyerang jika ancaman serangan dari negara lain tidak ditarik. Tidak seperti survival issues, vital issues tidak hanya tentang masalah pertahanan saja,tetapi juga ekonomi, tatanan dunia (aliansi dan prestise nasional) dan di beberapa kasus juga mengenai masalah ideologi.

iii) Major Issues: ketika politik, ekonomi dan ideologis negara dapat dipengaruhi oleh peristiwa dan trend pada dunia internasional dan karenanya memerlukan tindakan untuk mencegah ancaman sehingga tidak menjadi vital issues. Sebagian besar masalah dalam hubungan internasional termasuk dalam kategori ini dan biasanya diselesaikan melalui negosiasi diplomatik. Sebagian besar masalah ekonomi antara negara adalah termasuk major isuues dan bukan vital issues.

iv) Peripheral Issue: Ketika kesejahteraan negara tidak dipengaruhi oleh peristiwa atau tren di luar negeri, tetapi kepentingan pribadi warga dan perusahaan yang beroperasi di negara lain mungkin terancam. Perusahaan multinasional biasanya lebih dilindungi oleh negara asalnya dibandingkan kepentingan pribadi warga negara tersebut. Hal ini karena pendapatan dan pajak perusahaan multinasional memiliki pengaruh signifikan terhadap kesejahteraan ekonomi negara-negara tersebut.

Dari penjelasan tersebut jika dikaitkan dengan permasalahan yang terjadi di Indonesia khususnya pada permasalahan penanaman modal yang 
memberikan dampak bagi rakyat Indonesia, permasalahan tersebut dapat dikategorikan sebagai major Issues. Secara umum kepentingan nasional adalah sesuai dengan tujuan negara yang tercantum dalam pembukaan UUD NRI 1945 yang berbunyi: “....Melindungi segenap bangsa Indonesia dan seluruh tumpah darah Indonesia dan untuk memajukan kesejahteraan umum, mencerdaskan kehidupan bangsa, dan ikut melaksanakan ketertiban dunia yang berdasarkan kemerdekaan, perdamaian abadi dan keadilan sosial..."

Di Indonesia, bentuk dari kepentingan nasional yang diatur dalam UU PM adalah sebagai berikut: ${ }^{8}$

a. Memberikan perlindungan terhadap sumber daya alam.

b. Memberikan perlindungan dan mengembangkan usaha mikro, usaha kecil, usaha menengah dan koperasi.

c. Memberikan pengawasan kepada produksi dan distribusi.

d. Meningkatkan kapasitas teknologi.

e. Terdapat partisipasi modal dalam negeri dan kerjasama dengan badan usaha yang dibentuk oleh pemerintah.

f. Terlibat dalam kerjasama dengan badan usaha yang ditunjuk oleh pemerintah

Perlindungan kepentingan nasional dengan perspektif demokrasi ekonomi adalah menjadi jawaban perlindungan hukum yang paling tepat diterima masyarakat. Demokrasi ekonomi adalah sistem ekonomi nasional yang disusun sebagai usaha bersama berdasar atas asas kekeluargaan, dimana produksi dikerjakan oleh semua, untuk semua, di bawah pimpinan atau penilikan anggota-anggota masyarakat yang bertujuan untuk meningkakan kemampuan masyarakat dalam mengendalikan jalannya roda perekonomian. Sistem demokrasi ekonomi adalah sistem ekonomi nasional di Indonesia yang berasas kekeluargaan, berkedaulatan rakyat, bermoral Pancasila dan menunjukkan pemihakan sungguh-sungguh pada demokrasi ekonomi. Pemihakkan dan perlindungan ditujukan pada ekonomi rakyat yang sejak zaman penjajahan sampai saat ini Indonesia merdeka selalu terpinggirkan. Syarat mutlak berjalannya sistem ekonomi nasional yang berkeadilan sosial adalah berdaulat di bidang politik, mandiri di bidang ekonomi, dan berkpribadian di bidang budaya. ${ }^{9}$

Pasal 33 ayat (4) UUD NRI Tahun 1945 adalah tertulisnya istilah "efisiensi dan efektifitas". Artinya, perekonomian harus memberikan ruang kepada kepentingan pasar, tanpa menghilangkan peran negara. Faktanya, kondisi ekonomi global saat ini sangat dipengaruhi oleh paham individual-

${ }^{8}$ Rahmi Jened, Teori dan Kebijakan Hukum Investasi Langsung (Direct Investment), (Jakarta: Kencana ) 2016, hlm.362

${ }^{9}$ Mubyarto, dkk, Ekonomi Kerakyatan, ( Jakarta: Lembaga Suluh Nusantara \& American Institue For Indonesian Studies (AIFIS), 2014, hlm.8 
kapitalistik (free fight liberalisme) yang bertentangan dengan konstitusi Indonesia. Paham individual-kapitalistik memberikan kebebasan kepada pihak yang kuat untuk mendominasi pasar. Pasal 33 ayat (4) UUD NRI Tahun 1945 merupakan suatu penyelewengan yang akan dapat melumpuhkan paham "Kebersamaan dan Asas Kekeluargaan", atau minimal mendistorsi Pasal 33 UUD NRI Tahun 1945 dengan paham individualisme dan liberalisme ekonomi. ${ }^{10}$

Dalam perlindungan kepentingan nasional terhadap besarnya dampak penanaman modal dan beberapa produk kapitalisme yang tentunya sangat sulit untuk dihindari jika Indonesia sudah terlalu membuka pasar bebas, maka yang dibutuhkan dalam perlindungan kepentingan nasional adalah dengan menerapkan Demokrasi ekonomi. Demokrasi ekonomi bukan berarti menutup segala akses globalisasi namun memaksimalkan efek globalisasi yang baik untuk mensejahterakan negara.

Penjelasan lebih lanjut mengenai kepentingan nasional sebenarnya sangat terlalu konseptual. Namun bila dikaitkan dengan case saat ini yang terdampak adalah usaha kecil dan pemodalan usaha kecil seperti koperasi. Penyebutan perlindungan khusus pada UMKM dan Koperasi secara eksplisit ada pada Peraturan Presiden Republik Indonesia Nomor 76 Taun 2007 tentang Kriterian Dan Persyaratan Penyusunan Bidang Usaha yang Tertutup dan bidang Usaha yang Terbuka dengan Persyaratan di Bidang Penanaman Modal.

Pada peraturan tersebut beberapa bidang usaha yang terbuka dengan persyaratan harus memperhatikan perlindungan dan engembangan Usaha Mikro, Kecil, Menengah dan Koperasi (UMKMK). Ini membuktikkan bahwa penanaman modal amat bersinggungan secara langsung dengan aktivitas penanaman modal terutama Asing.

Keberadaan UMKM dan Koperasi sebagai bagian terbesar dari seluruh entitas usaha nasional merupakan wujud nyata kehidupan ekonomi rakyat Indonesia. Posisi seperti itu seharusnya menempatkan peran UMKM dan Koperasi sebagai salah satu pilar utama dalam mengembangkan sistem ekonomi kerakyatan, namun hingga kini perkembangannya masih jauh tertinggal dibandingkan dengan pelaku ekonomi yang lain dan juga UMKM dan Koperasi dapat dikatakan terlupakan oleh keberadaaan PMA.

Oleh karena itu pengembangan UMKM dan Koperasi harus menjadi salah satu strategi utama pembangunan nasional yang pelaksanaannya diwujudkan secara sungguh-sungguh dengan komitmen bersama yang kuat

${ }^{10}$ Sri-Edi Swasono, Dalam Seminar Implementasi Pasal 33 Dan Pasal 34 UUD NRI Tahun 1945 Gerakan Jalan Lurus, Jakarta, 6 Agustus 2008. Dalam Agung Rifqi Pratama, Sistem Ekonomi Indonesia dalam Perspektif Pancasila dan Undang-Undang Negara Republik Indonesia Tahun 1945, Jurnal Vej, Vol.4 No.2, 2018, hlm.327 
serta didukung oleh upaya-upaya sistematis dan konseptual secara konsisten dan terus menerus dengan melibatkan semua pihak yang berkepentingan (baik pemerintah, swasta, maupun masyarakat di tingkat nasional, regional, maupun lokal). Barang tentu hal ini juga harus dibarengi dengan strategi pengembangan usaha besar dalam kerangka sistem ekonomi kerakyatan. Konsep pengembangan UKM dan Koperasi dalam sistem ekonomi kerakyatan seyogyanya mempunyai perspektif tentang pentingnya: (a) peran serta aktif seluruh komponen masyarakat; (b) jiwa dan semangat kewirausahaan yang tinggi; (c) kebebasan berusaha, berkreasi dan berinovasi; (d) kesempatan yang sama dalam memperoleh pendidikan, teknologi dan informasi; (e) sistem ekonomi yang terbuka, transparan dan efisien; dan (f) mekanisme pasar yang berkeadilan. ${ }^{11}$

\section{Penguatan Sistem UMKM Sebagai bentuk Perlindungan Hukum Kepentingan Nasional}

Prinsip perlindungan dalam hukum ekonomi terutama kegiatan UMKM adalah mencakup: ${ }^{12}$

(1) Prinsip ekonomi dalam UUD 1945, prinsip ini seperti dirumuskan oleh the founding father atau pembentuk UUD 1945 yang telah memikirkan dengan matang bangunan ekonomi bagi bangsa Indonesia, melalui prinsip ekonomi guna mencapai tujuan nasional yaitu masyarakat adil dan makmur. Artinya kemakmuran rakyat dapat diperoleh melalui kegiatan ekonomi yang betulbetul sehat dan jauh dari praktik-praktik persaingan usaha tidak sehat. Apabila diperhatikan dengan seksama, ada 7 (tujuh) asas prinsip ekonomi yang dimuat dalam Pasal 33 UUD 1945, yaitu: ${ }^{13}$ keseimbangan, keserasian dan keselarasan, persamaan, usaha bersama, kekeluargaan, musyawarah untuk mufakat (demokrasi ekonomi), manfaat, perlindungan dan pembinaan pihak yang lemah;

(2) Prinsip perlindungan kepentingan nasional. Ketentuan dalam Pasal 33 ayat (2) dan (3) UUD 1945 diatur mengenai penguasaan negara atas cabang-cabang produksi yang memenuhi kepentingan nasional. Penguasaan sebagai bentul daripada kepentingan nasional. Penguasaan Negara atas cabang-cabang produksi tersebut didasarkan pada upaya untuk dapat melindungi kepentingan rakyat banyak guna

${ }^{11}$ Ibid, hlm.27

12 Ade Komarudin, Politik Hukum Integratif UMKM, Kebijakan Negara Membuat UMKM Maju dan Berdaya Saing, (Jakarta: PT Semesta Rakyat Merdeka, 2014), hlm. 2021

13 Jimly Asshiddiqie, Konstitusi Ekonomi, (Jakarta: Kompas Media Nusantara, 2010), hlm. 282. 
memenuhi kebutuhan primer dan perilaku pengusaha tidak baik yang menguasai sumber daya di dalam bentuk monopoli. Perlu dikemukakan bahwa prinsip perlindungan kepentingan nasional yang ditetapkan berarti ada kepentingan umum yang tidak boleh bersifat kontraproduktif terhadap asas kebebasan berkontrak. Artinya demi kepentingan umum dan nasional, ruang gerak kebebasan berkontrak bagi para pelaku usaha tidak semakin sempit dalam kegiatan bisnis. Apabila ini terjadi, sama saja tidak ada pengakuan negara terhadap asas kebebasan berkontrak, sekalipun untuk perlindungan kepentingan umum/nasional, karena mematikan pengusaha dalam berbisnis;

(3) Prinsip perlindungan dalam hukum internasional dan hukum perdata. Selain aspek hukum nasional yang berupaya meningkatkan kemampuan daya saing produk barang dan jasa dalam negeri, perekonomian nasional juga harus memperhatikan prinsip perlindungan hukum internasional. Perlindungan ini akan mempengaruhi reputasi ekonomi dan perlakuan negara lain terhadap kegiatan pemasaran produk-produk Indonesia, baik di dalam maupun luar negeri. Perlindungan hukum internasional dan hukum perdata internasional dalam kerangka perdagangan antar negara melalui pelbagai sarana transportasi dan komunikasi saling menghormati berdasarkan perjanjian internasional dan prinsip pacta sunt servanda, yaitu perjanjian yang telah disepakati berlaku sebagai undangundang bagi pihak yang menyelenggarakan perjanjian;

(4) Prinsip perlindungan bagi golongan ekonomi lemah. Berbagai ketentuan yang mengatur pengembangan UMKM selama ini menunjukkan perhatian pemerintah terhadap pengusaha kecil. Di antara ketentuan tersebut adalah Undang-Undang Nomor 20 tahun 2008 tentang Usaha Mikro Kecil dan Menengah sebagai upaya perlindungan hukum untuk pengusaha kecil, sehingga pembinaan pasar bagi usaha kecil harus merupakan suatu sistem terpadu, karena pengembangannya tergantung dari interaksi unsur organisasi dari para pengusaha kecil dan komponen pendukung dari kebijakan eknomi pemerintah, usaha menengah dan usaha besar yang dapat saling membantu dan mempengaruhi;

(5) Prinsip perlindungan kepentingan nasional dalam GATT. Kepentingan ekonomi nasional suatu negara perlu dilindungi dari praktik bisnis curang, baik yang dilakukan oleh pengusaha di dalam negeri maupun pengusaha asing. Begitu juga oleh Negara industri maju terhadap negara berkembang melalui kebijakan ekonomi yang dapat menghalangi masuknya barang ekspor dan impor ke negara tersebut. Prinsip dan perlindungan kepentingan nasional ini tetap diakui di 
dalam ketentuan GATT sebagai bentuk pengecualian dari prinsip umum terhadap industri dan negara tertentu pada kegiatan ekonomi dunia; ${ }^{14}$

(6) Prinsip persaingan usaha yang sehat. Kegiatan bisnis modern yang ketat dan penuh persaingan menimbulkan perlakuan kurang adil dan sering dialami oleh pihak ekonomi lemah. Pengusaha yang kuat dan serakah dengan berbagai cara berusaha untuk menguasai pasar nasional, regional dan internasional. Praktik curang tidak hanyadilakukan berdasarkan perbuatan melawa hukum (onrechtmatige daad) dalam hukum perdata, ${ }^{15}$ akan tetapi juga berupa penyalahgunaan hak yang merugikan bagi pengusaha dan negaranegara berkembang mengekspor produk berupa bahan mentah, barang setengah jadi atau kerajinan. Bentuk persaingan curang (unfair competition) tidak dapat ditolerir dan perlu dicegah dan dikurangi di dalam kegiatan bisnis, baik melalui peraturan perundang-undangan maupun dalam bentuk putusan hakim dan kebijakan ekonomi pejabat eksekutif. Klausula kontrak bisnis yang curang secara nyata melahirkan keuntungan tidak wajar atau tidak sebanding besarnya pada satu pihak. Sebaliknya, pihak-pihak yang lain karena ketidaktahuan atau kelemahan tertentu yang dihadapinya semakin terdesak kedudukan ekonominya dalam angka persaingan pasar; ${ }^{16}$

Berdasarkan kebijakan yang ada, maka yang terpenting adalah penciptaan iklim usaha kecil. Hal ini dirumuskan Pasal 7 Undang-Undang Nomor 20 Tahun 2008 tentang Usaha Mikro, Kecil, dan Menengah yang dilakukan melalui penetapan peraturan perundang-undangan dan kebijakan perlindungan bagi ekonomi lemah. Namun dalam undang-undang tersebut tidak ditegaskan tentang bentuk peraturan bentuk peraturan perundangudangan yang harus dikeluarkan untuk dapat mengatur dan melaksanakan lebih lanjut mengenai perlindungan yang harus diberikan kepada UMKM. ${ }^{17}$ Atas dasar hal tersebut bentuk-bentuk perlindungan hukum UMKM dalam rangka mensejahterkan masyarakat yang harus dilakukan oleh pemerintah adalah sebagai berikut: ${ }^{18}$ hlm. 64.

${ }^{14}$ Munir Fuady, Perbuatan Melawan Hukum, (Jakarta : Citra Aditya Bakti,) 2010,

15 Teguh Sulistia, Pengaturan Usaha Kecil Dalam Ekonomi Kerakyatan, Disertasi, (Surabaya, Pascasarjana Universitas Airlangga, 2006), hlm. 35.

${ }^{16}$ Ade Komarudin, Op.cit, hlm. 23.

${ }^{17}$ Ibid

${ }^{18}$ Dhaniswara K. Harjono, UMKM Butuh Perlindungan Hukum Dalam Menghadapi MEA, situs online, http://www.hukumonline.com/berita/baca/lt54291034f072b/umkmbutuh-perlindungan-hukum-dalam-menghadapi-mea-2015, Diakses pada tanggal 29 Desember 2020 
(1) syarat dan tata cara permohonan izin usaha yang lebih dipermudah agar UMKM dapat lebih cepat bersaing untuk melakukan usaha nya, selama ini yang terjadi UMKM kesulitan mendapatkan atau dikeluarkan izin usaha;

(2) tata cara pengembangan, pengembangan UMKM harus lebih digiatkan. Hal ini tentu saja dengan peran dari pemerintah untuk mendukung pengembangan UMKM, hal ini bisa dimulai dengan peningkatan SDM sehingga meningkatkan mutu dan kulitas dari hasil UMKM tersebut;

(3) prioritas, UMKM harus menjadi prioritas pemerintah, hal ini dilihat sewaktu krisismoneter yang terjadi di Indonesia, UMKM mampu tetap tumbuh dan berkembang sampai dengan sekarang;

(4) intensitas dan jangka waktu pengembangan, intensitas dari bisnis UMKM harus memiliki roadmap yang jelas serta capaian yang pasti setiap semesternya, selain itu waktu pengembangan harus semakin dipacu, hal ini untuk membuat UMKM semakin kokoh di dalam perannya mensejahterakan masyarakat;

(5) pola kemitraan, UMKM harus memiliki pola kemitaraan dalam memasarkan produknya, sehingga kegiatan output UMKM jelas dan terarah serta mampu bersaing di pasar nasional ataupun pasar kelas mancanegara;

(6) penyelenggaraan kordinasi dan pengendalian pemberdayaan UMKM, koordinasi dan pengendalian pemberdayaan UMKM dari pusat ke daerah dan sebaliknya dari pusat ke daerah harus jelas dan berimbang, aturanaturan yang ada seharusnya menguntungkan UMKM, bukan menjadikan UMKM semakin merugi karena aturan-aturan yang membuat mereka kesulitan; dan

(7) tata cara pemberian sanksi administratif, harus diatur tata cara pemberian sanksi administratif bagi UMKM yang bertindak curang atau bahkan adanya perusahaan besar yang memonopoli pasar, sehingga UMKM tidak mampu memasarkan barang dagangannya.

Selain itu menyangkut keadilan, kepastian hukum, dan manfaat. Negara seharusnya melakukan sesuatu yang sifatnya reformasi, salah satunya dengan memberikan bantuan hukum gratis untuk UMKM dan pemutihan pajak. Hal ini mengingat hukum tidak hanya berperan untuk menjamin adanya kepastian dan ketertiban semata, sebagaimana halnya konsep Negara penjaga malam. Akan tetapi hukum juga harus berfungsi untuk mempercepat proses pembangunan nasional. Menurut Mochtar Kusumaatmadja, hukum diharapkan berfungsi lebih daripada sekedar itu, yakni dapat sebagai sarana pembaharuan masyarakat atau sarana 
pembangunan dengan pokok-pokok pikiran sebagai berikut: ${ }^{19}$ hukum merupakan sarana pembaharuan masyarakat didasarkan kepada anggapan bahwa adanya keteraturan atau ketertiban dalam usaha pembangunan dan pembaharuan itu merupakan suatu yang diinginkan atau dipandang (mutlak) perlu.

\section{Pengembangan Koperasi Sebagai bentuk Perlindungan Hukum Kepentingan Nasional}

Pengembangan UMKM dan Koperasi menjadi komponen penting bagi program pembangunan nasional untuk meletakkan landasan pembangunan sistem ekonomi kerakyatan yang berkelanjutan dan berkeadilan. Proses dan cara untuk mencapai tujuan pembangunan tersebut sangat penting, terutama melalui upaya penguatan kelembagaan dan peningkatan kapasitas. Pendekatan demikian diharapkan lebih menjamin terwujudnya perekonomian yang lebih adil dan merata, berdaya saing dengan basis efisiensi di berbagai sektor dan keunggulan kompetitif untuk memenangkan persaingan global, berwawasan pemanfaatan sumberdaya alam dan lingkungan hidup yang lestari, dengan partisipasi masyarakat yang lebih menonjol dan desentralisasi pembangunan untuk meningkatkan kapasitas dan memaksimalkan potensi daerah, serta bersih dari KKN. ${ }^{20}$

Program penyelamatan dan pemulihan ekonomi nasional hendaknya tidak hanya dipandang sebagai crash-program yang bersifat sementara, tetapi juga harus dipandang sekaligus sebagai proses percepatan transformasi struktural dan pembangunan yang berkelanjutan untuk meletakkan landasan bagi terwujudnya struktur ekonomi yang kuat dengan peran serta masyarakat dan dunia usaha yang lebih besar, terutama kontribusi UKM dan Koperasi dalam pembentukan nilai tambah, kepemilikan aset dan daya saing. Artinya upaya pengembangan UKM dan Koperasi sekaligus merupakan pilihan strategis dalam rangka membangun daya saing dan ketahanan ekonomi nasional serta untuk mewujudkan sistem eknomi kerakyatan. Peningkatan daya saing usaha nasional dalam persaingan harus dicapai secara bersamaan dengan pembangunan kemampuan ekonomi masyarakat yang tertinggal. Peran UKM dan Koperasi cukup berarti di dalam proses pembangunan, karena industri besar terbukti tidak bisa menjadi pemeran tunggal dalam memecahkan: (a) pengangguran dan setengah pengangguran di negara-negara berkembang, (b) ketidakmerataan distribusi pendapatan, dan (c) ketidakseimbangan struktur pembangunan ekonomi sektoral dan regional atau desa-kota.

19 Mochtar Kusumaatmadja, Hukum, Masyarakat, dan Pembinaan Hukum Nasional, (Bandung: Binacipta, 1995), hlm.13.

${ }^{20}$ Ibid 
Perkembangan teknologi yang diikuti dengan cepatnya perubahan selera konsumen semakin memperpendek daur hidup produk (product life cycle). Sementara itu dari segi potensi, usaha kecil dan menengah (UKM) merupakan skala usaha yang dinamis yang memiliki daya responsif, fleksibilitas dan adaptasi yang tinggi terhadap perubahan teknologi dan pasar. Dalam kaitannya dengan krisis ekonomi yang tengah terjadi saat ini, usaha nasional perlu diselamatkan, dibangkitkan kembali, dan diperkuat, terutama UMKM dan Koperasi yang terbukti memiliki fleksibilitas lebih tinggi untuk beradaptasi terhadap perubahan. Dengan demikian dalam krisis ini UMKM dan Koperasi diharapkan mampu lebih berperan dalam mengatasi pengangguran, pemenuhan ketersediaan kebutuhan masyarakat, dan menggerakkan kembali roda perekonomian nasional.

Lebih dari satu dasawarsa pasca reformasi, pengaturan koperasi baru diganti. Adalah Undang-Undang Nomor 17 Tahun 2012 tentang Perkoperasian yang menggantikan Undang-Undang Nomor 25 Tahun 1992. Sayangnya Undang-Undang ini "jauh panggang dari api" untuk memajukan koperasi. Hal ini justru melemahkan koperasi dan bertentangan dengan Undang-Undang Dasar. Undang-Undang ini baru dua tahun berjalan kemudian dibatalkan secara keseluruhan oleh Mahkamah Konstitusi. Undang-Undang Koperasi dianggap sudah kehilangan ruhnya sebab tidak lagi mendasari pada prinsip-prinsip koperasi. Koperasi didesain seperti halnya perusahaan kapitalisme yang semata-mata mencari keuntungan, bukan bertujuan untuk mensejahterakan anggotanya. Bahkan koperasi dalam definisinya menjadi lahan utuk mencari keuntungan oleh oranag peroranagan. Dalam pengujian ini Mahkamah mengabulkan permohonan pemohon dan membatalkan keseluruhan Undang-Undang nomor 17 Tahun 2012 dengan beberapa pertimbangan. ${ }^{21}$

Menurut Baswir UU Koperasi No.25 Tahun 1992 harus diperbaharui. Koperasi sejati tidak sama dengan koperasi "persekutuan majikan" yang keanggotaannya bersifat tertutup dan dibatasi pada segelintir pemilik modal, sebagaimana saat ini. Koperasi sejati adalah koperasi yang modalnya dimiliki secara kolektif oleh seluruh konsumen dan karyawan koperasi tersebut. Dengan kata lain, koperasi sejati adalah koperasi yang tidak mengenal diskriminasi agama, sosial, ras dan antar golongan dalam menentukan kriteria keanggotaannya. Sebagai titik tolak dalam melakukan pembaharuan UU Koperasi ini, UU Koperasi Nomor 79 tahun 1958 patut dipertimbangkan sebagai bahan pembanding. ${ }^{22}$

${ }^{21}$ Mochmad Adib Zain, Politik Hukum Koperasi di Indonesia ( Tinjauan Yuridis Historis Pengaturan Perkoperasian di Indonesia), Jurnal Penelitian Hukum, Vol.2 No.3 November 2015, hlm.173

${ }^{22}$ Revrisond Baswir, Op.cit, hlm.140 
Selain itu menyangkut keadilan, kepastian hukum, dan manfaat. Negara seharusnya melakukan sesuatu yang sifatnya reformasi, salah satunya dengan memberikan bantuan hukum gratis untuk UMKM dan pemutihan pajak. Hal ini mengingat hukum tidak hanya berperan untuk menjamin adanya kepastan dan ketertiban semata, sebagaimana halnya konsep Negara penjaga malam. Namun hukum juga harus berfungsi untuk mempercepat proses pembangunan nasional. Menurut Mochtar Kusumaatmadja, hukum diharapkan berfungsi lebih daripada sekedar itu, yakni dapat sebagai sarana pembaharuan masyarakat atau sarana pembangunan dengan pokok-pokok pikiran sebagai berikut: ${ }^{23}$ hukum merupakan sarana pembaharuan masyarakat didasarkan kepada anggapan adanya keteraturan atau ketertiban dalam usaha pembangunan dan pembaharuan itu merupakan suatu yang diinginkan atau dipandang (mutlak) perlu. $^{24}$

Dalam melindungi kepentingan nasional dari dampak terbukanya penanaman modal dibutuhkan eksistensi koperasi dan UMKM yang serius, penanaman modal dapat memancing ancaman resisi global yang sangat berpengaruh terhadap sistem perekonomian nasional. Saat ini misalnya kita dihadapkan dengan ancaman resisi global yang bisa terjadi sewaktu-waktu, seperti adanya perang dagang yang dilakukan Amerika dan Cina. Situasi ini akan menekan neraca perdagangan dalam negeri, mengingat kedua negara tersebut merupakan mitra dagang utama di Indonesia. Penguatan koperasi dan UMKM merupakan upaya perlindungan preventif berbasis demokrasi ekonomi yang dapat dilakukan terhadap dampak penanaman modal.

\section{KESIMPULAN}

Perlindungan hukum terhadap kepentingan nasional dalam penanaman modal di Indonesia sangat penting mengingat perdagangan global saat ini sudah memasuki tahapan tanpa batasan, sehingga berpotensi muncul banyak gesekan akibat bersinggungan langsung kepentingan pihak asing dan dalam negeri. Keran investasi yang dibuka lebar juga akan banyak memancing penanaman modal asing dan modal besar yang akan membawa banyak pengaruh serta resiko tertentu yang memungkinkan adanya ketidakseimbangan iklim usaha, terutama bagi usaha kecil menengah yang dijalankan oleh rakyat. Dengan adanya perlindungan hukum yang jelas memberi perlindungan khusus kepentingan nasional berdasarkan demokrasi ekonomi dalam penanaman modal tentu akan menciptakan keseimbangan

23 Mochtar Kusumaatmadja, Hukum, Masyarakat, dan Pembinaan Hukum Nasional, (Bandung: Binacipta, 1995), hlm.13., Dalam Laurensius Arliman S, ibid, hlm.400 
iklim usaha serta meningkatkan peran rakyat dalam perekonomian nasional di tengah globalisasi. Perlindungan hukum terhadap kepentingan nasional dalam penanaman modal apabila ditinjau dengan demokrasi ekonomi akan memunculkan dua aspek utama yang harus segera dieksekusi oleh Pemerintah, yakni penguatan sistem UMKM serta pengembangan koperasi. Hal ini merujuk pada pembangunan sistem ekonomi yang sesuai dengan cita-cita tolong menolong, sebagaimana amanat konstitusi. Dengan dilaksanakannya kedua hal tersebut akan membentuk suatu perlindungan khusus, yang menempatkan UMKM dan koperasi pada tingkatan khusus sehingga memiliki peran yang signifikan dalam perekonomian nasional.

\section{DAFTAR PUSTAKA}

\section{Buku}

Arliman S, Laurensius, Perlindungan Hukum UMKM dari Eksploitasi Ekonomi dalam Rangka Peningkatan Kesejahteraan Masyarakat, Jurnal RechtsVinding, Vol.6 No.3 Desember 2017.

Asshiddiqie, Jimly, Konstitusi Ekonomi, (Jakarta: Kompas Media Nusantara, 2010).

Diantha, I.M.P., Metodologi Penelitian Hukum Normatif dalam Justifikasi Teori Hukum, (Jakarta: Prenada Media, 2016).

Fuady, Munir, Perbuatan Melawan Hukum, (Jakarta : Citra Aditya Bakti,) 2010.

Janed, Rahmi, Teori dan Kebijakan Hukum Investasi Langsung (Direct Investment), (Jakarta: Kencana, 2016).

Komarudin, Ade, Politik Hukum Integratif UMKM, Kebijakan Negara Membuat UMKM Maju dan Berdaya Saing, (Jakarta: PT Semesta Rakyat Merdeka, 2014).

Kusumaatmadja, Mochtar, Hukum, Masyarakat, dan Pembinaan Hukum Nasional, (Bandung: Binacipta, 1995).

Mubyarto, dkk, Ekonomi Kerakyatan, (Jakarta: Lembaga Suluh Nusantara \& American Institue For Indonesian Studies (AIFIS), 2014.

Nuechterlein, Donald E, National Interests and Foreign Policy: A Conceptual Framework for Analysis and Decision-Making. British Journal of International Studies. Vol. 2, 1976, Dalam Chaindra Adityas Ramadhan, Kepentingan Nasional Indonesia Terhadap Jepang dalam Japan-Indonesia Maritime Forum periode 2017-2018, Skripsi, Fakultas Ilmu Sosial dan Ilmu Politik, Universitas Lampung, 2019. 
Revrisond Baswir, Manifesto Ekonomi Kerakyatan, (Yogyakarta: Pustaka Pelajar, Cetakan ke III, 2016).

Sulistia, Teguh, Pengaturan Usaha Kecil Dalam Ekonomi Kerakyatan, Disertasi, (Surabaya, Pascasarjana Universitas Airlangga, 2006).

\section{Jurnal}

Kader, Mukhtar Abdul, Peran UKM dan Koperasi dalam Mewujudkan Ekonomi Kerakyatan di Indonesia, Jurnal Riset Bisnis dan Manajemen, Vol.8 No.1, April 2018.

Sri-Edi Swasono, dalam Seminar Implementasi Pasal 33 Dan Pasal 34 UUD NRI Tahun 1945 Gerakan Jalan Lurus, Jakarta, 6 Agustus 2008. Dalam Agung Rifqi Pratama, Sistem Ekonomi Indonesia dalam Perspektif Pancasila dan Undang-Undang Negara Republik Indonesia Tahun 1945, Jurnal Vej, Vol.4 No.2, 2018.

Zain, Mochmad Adib, Politik Hukum Koperasi di Indonesia ( Tinjauan Yuridis Historis Pengaturan Perkoperasian di Indonesia), Jurnal Penelitian Hukum, Vol.2 No.3 November 2015.

\section{Artikel Ilmiah}

Brooks, Dalam Prabowo Siswanto, Analisis Dampak Perdagangan Bebas Terhadap Ketimpangan Pembangunan Wilayah, Artikel Ilmiah, Universitas Dipenegoro, 2011.

Dwitari, Erika, Andriyanto, "Asean-Cina Free Trade Area Agreement as an International Regime: The Impact Anlysis on Asean", Artikel Ilmiah, Jurusan Hubungan Internasional, Fakultas Sosial Politik, Universitas Indonesia, 2013.

\section{Internet}

Hariono, Dhaniswara K., UMKM Butuh Perlindungan Hukum Dalam Menghadapi MEA, situs online, http://www.hukumonline.com/berita/baca/lt54291034f072b/umkmbutuh-perlindungan-hukum-dalam-menghadapi-mea-2015, diakses pada tanggal 29 Desember 2020 